\title{
Apresentação Seção Especial
}

\author{
MARIA WALDENEZ DE OLIVEIRA ${ }^{1}$ \\ Universidade Federal de São Carlos, UFSCAR, SÃo CARLos-SP, BraSIL
}

Não te esperarei na pura espera porque o meu tempo de espera é um tempo de quefazer (FREIRE, 2000, p. 5).

A temática dos Processos Educativos é investigada há 23 anos pelo Grupo de Pesquisa "Práticas Sociais e Processos Educativos" e, desde 2005, pela Linha de Pesquisa homônima do Programa de Pós-Graduação em Educação (PPGE) da Universidade Federal de São Carlos (UFSCar). Entre os vários espaços formativos e de diálogos vimos, desde 2009, realizando Seminário de Pesquisas em Práticas Sociais e Processos Educativos em que compartilhamos resultados de teses e dissertações concluídas ou em fase de finalização, além de ensaios com reflexões teóricas e metodológicas sobre Processos Educativos em Práticas Sociais ${ }^{2}$.

Além dos seminários de pesquisa, temos seminários de aprofundamento de estudos e de debates, como por exemplo, no ano 2018, problematizando os 130 anos da Abolição da Escravatura.

No ano de 2019 foi realizado o $6^{\circ}$ Seminário, para o qual colocamos como tema o esperançar ${ }^{3}$. Mergulhados em vivências e notícias diárias de crises ambientais e humanas, violências de todo tipo, discriminações, históricas, é bom que se diga, num horizonte pouco alentador, para este $6^{\circ}$ Seminário colocamo-nos o desafio de discutir o esperançar em nossas pesquisas. Nele indagamo-nos como, ao pesquisar Práticas Sociais e Processos Educativos, podemos contribuir para visibilizar, valorizar, pensar, criticar, construir, semear o esperançar. Usamos o verbo esperançar, pois entendemos esperança como ação, movimento e que o mundo é obra e não espetáculo. Falta de esperança é reduzir demais a esperança ao esperar, à uma promessa de que algo melhor será feito por alguém sem mim. Diante dessas reflexões, intitulamos esse Seminário como "Reflex-ações no esperançar" apontando, nesse título, a necessidade do movimento de emersão e imersão, de reflexão e ação como diz Paulo Freire na Epígrafe desta Apresentação. Esse movimento não é distinto ou anterior, ou posterior ao esperançar, mas ocorre conosco mergulhados e mergulhadas nele, cotidianamente. Em 2019 foi lançada a Campanha Latino-Americana e Caribenha em Defesa do Legado de Paulo Freire. Fizemos também do Seminário uma homenagem a esse legado ao lançar como tema central gerador de nossas discussões o esperançar freireano, o movimentar-se em direção ao "inédito viável" como nos ensina nosso Patrono da Educação.

Inédito viável se constrói na dialogicidade em comunidade crítica de trabalho, "[...] pelo mundo afora e pela tradição adentro" (KAYAPÓ; KAYAPÓ, 2019, p. 21), enraizados e enraizadas. Mas de que raízes estamos falando? Com esta problematização em mente, decidimos que a conferência de abertura ficaria a cargo de um representante de povos indígenas para nos trazer seu entendimento acerca dessas raízes e desse movimento de esperançar enraizado. Tendo o entendimento da pesquisa como processo também político e de

\footnotetext{
${ }^{1}$ Professora Titular da UFSCar. Co-líder do Grupo de Pesquisa "Práticas Sociais e Processos Educativos". Email: dmwo@ufscar.br. ORCID: http://orcid.org/0000-0001-6362-8581.

2 Para mencionar alguns temas anteriores deste Seminário de Pesquisa, tivemos: "90 anos do nascimento de Paulo Freire" (2011); "Contribuições da Profa. Petronilha Beatriz Gonçalves e Silva" (2013); "Educar-se em Direitos Humanos" (2014).

${ }^{3}$ O verbo "esperançar" indica ação e uma contraposição ao verbo esperar, como expresso na epígrafe.
} 
resistência e criação, trata-se de evidenciar, reconhecer, tomar como base e processo da ciência que produzimos, conhecimentos, culturas, modos de ser-resistir daqueles e daquelas a quem se tentou convencer serem seres menos, seres não humanos, não seres. Seres e culturas que sobreviveram e sobrevivem à espoliação material e cultural e da vida. Com essas reflexões convidamos Kaká Werá ${ }^{4}$, indígena da etnia tapuia, para proferir a Conferência de Abertura, tendo sido intitulada "Esperançar: conectar raízes para construir ações" .

Em seguida à conferência, tivemos dois dias de apresentações dos trabalhos, alguns dos quais estão sendo publicados com atualizações e adequações nesta seção especial da "Motricidades: Revista da Sociedade de Pesquisa Qualitativa em Motricidade Humana". O primeiro trabalho "Fútbol callejero: esperançando alteridade", de autoria de Maurício Mendes Belmonte e Luiz Gonçalves Junior, apresenta essa prática social a qual estabelece interface entre o jogo de futebol com os horizontes emancipatórios-libertadores da Educação Popular. Analisam que essa prática contribuiu para a fruição do processo educativo da alteridade e, desde esta perspectiva, o ser-mais freireano. No artigo "Os 'aulões' nos espaços de privação de liberdade como ato de esperança", Luciana Ferreira da Silva Moraes e Elenice Maria Cammarosano Onofre analisam a atividade de preparo e desenvolvimento de aulas baseadas em um tema gerador - denominadas "aulões" - e que acontecem em espaços de privação de liberdade nos municípios de Cuiabá e Várzea Grande, estado de Mato Grosso. Concluem as autoras, que os "aulões" se apresentam como possibilidade de educação libertadora mesmo em um espaço com normas rígidas e opressoras como a prisão. Seguem-se Djalma Ribeiro Junior e Maria Waldenez de Oliveira, no ensaio "Processos educativos pelas veredas do esperançar", nos apontando, a partir das experiências de comunicação popular da Mostra de Audiovisual de Cambuquira (MG), que a construção do esperançar pode se dar por meio de algumas dimensões, das quais o artigo destaca o diálogo, o convívio dialógico e a comunhão de projetos de mundo que encaminham a construção de conhecimentos com compromisso social. A seguir, temos o ensaio "Vivências de Jongo com crianças na escola: educação das relações étnico-raciais", de Vívian Parreira da Silva e Aida Victória Garcia Montrone, apresentando experiências fundamentadas em vivências de Jongo numa escola na cidade de São Carlos (SP) com crianças de 6 e 7 anos, como caminho possível para práticas educativas antirracistas. As autoras concluem que os processos educativos vivenciados em diálogo com os saberes jongueiros são ferramentas de luta ancestral para esperançarmos uma educação que promova vida, diversidade, afeto e coragem.

Desejamos que os artigos propiciem leituras críticas que alimentem esperanças, conexões, ações, rebeldias. Boas leituras.

\section{REFERÊNCIAS}

FREIRE, P. Pedagogia da indignação: cartas pedagógicas e outros escritos. 1. reimp. São Paulo: Editora UNESP, 2000.

KAYAPÓ, A. N L.; KAYAPÓ, E. Amor originário: povo mebengôkré kayapó. In: NEGRO, M. (org.). Nós: uma antologia de literatura indígena. São Paulo: Companhia das Letrinhas, 2019. p. 12-25.

\footnotetext{
${ }^{4}$ Informações sobre Kaká Werá podem ser acessadas em: https://www.kakawera.com/about-me.

${ }^{5}$ A Conferência pode ser visualizada em: https://www.youtube.com/watch?v=k_enzUWBgeM.
} 